\title{
Effect of pH extraction buffer on antioxidant enzymes activities in water lily's leaves and petioles
}

\author{
${ }^{1}$ Mohd Zin, Z., ${ }^{1}$ Yahaya, N.H., ${ }^{1}$ Bashah, N., ${ }^{2}$ Ibrahim, K., ${ }^{3,4}$ Rusli, N.D., ${ }^{5}$ Smedley, K.L., \\ ${ }^{6}$ Mohd, K.S. and ${ }^{1, *}$ Zainol M.K. \\ ${ }^{1}$ Faculty of Fisheries and Food Science, Universiti Malaysia Terengganu, Mengabang Telipot, 21030, \\ Kuala Nerus, Terengganu, Malaysia \\ ${ }^{2}$ Centre for Foundation and Continuing Education, Universiti Malaysia Terengganu, Mengabang Telipot, \\ 21030, Kuala Nerus, Terengganu \\ ${ }^{3}$ Faculty of Agro-based Industry, Universiti Malaysia Kelantan, Jeli, Kelantan, Malaysia \\ ${ }^{4}$ Institute of Food Security and Sustainable Agriculture, Universiti Malaysia Kelantan, Jeli, Kelantan, \\ Malaysia \\ ${ }^{5}$ Stratford School, Stratford-upon-Avon, Warwickshire, CV37 9DH, United Kingdom \\ ${ }^{6}$ School of Agriculture Science and Biotechnology, Faculty of Bioresources and Food Industry, Universiti \\ Sultan Zainal Abidin, Besut Campus, Besut 22200, Terengganu, Malaysia
}

\begin{abstract}
Article history:
Received: 23 February 2021

Received in revised form: 26

March 2021

Accepted: 10 June 2021

Available Online: 16 January 2022
\end{abstract}

\section{Keywords:}

Antioxidant activities,

Nymphaea antares,

Water lily,

$\mathrm{pH}$ extraction

DOI:

https://doi.org/10.26656/fr.2017.6(1).130

\section{Introduction}

Native aquatic plants generally grow and adapt to a particular environment that is at least frequently filled with water, such as in a wetland, as these aquatic plants grow in permanently or seasonally wet environments (Knight et al., 2014). One of the species included in this group is water lily (Nymphaeceae) (Lacoul and Freedman, 2006). Water lily (Nymphaea antares) is one of the most valuable aquatic ornamental plants which have a bright potential in the floriculture industry (Pareek and Kumar, 2016). Water lily is an aquatic herb of genus Nymphaea, from family Nymphaeaceae (Chen et al., 2017), a precious perennial aquatic flower plant that is divided into two ecological classes, namely tropical and hardy water lily (Zhu et al., 2012). Water lily is, frequently found along the edges of ponds, lakes, and streams (Crane and Friis, 2020). This plant has various functions for example the whole flowers and roots can be made into tea while the alkaloid-rich leaves have been used medicinally since ancient times (Les, 2002). The whole plant aqueous decoction is used by 'Hausas' in Northern Nigeria for the treatment of Guinea worm infection and 'Yoruba' in Southern West Nigeria for the treatment of rheumatic pain and as an antitumor agent (Ogbadoyi et al., 2007). The antibacterial (Akinjogunla et al., 2010), antidiabetic (Dodamani et al., 
2012) and antioxidant (Afolayan et al., 2013) effects of this plant have also been documented.

Antioxidants are compounds that act as the first defence for our body against free radical damage and are vital in sustaining optimum health and well-being (Zainol et al., 2018). Antioxidant compounds act as a major function in our body due to favourable effects on our health (Dian-Nashiela et al., 2015). Free radicals or reactive oxygen species (ROS) are compounds formed when oxygen combines with other molecules (Chong et al., 2018). There are two groups of ROS that can be found that are oxygen-centred radical and oxygencentred non-radicals. Oxygen-centred radicals are superoxide ion $\left(\mathrm{O}_{2}{ }^{-}\right)$, hydroxyl radical $(\mathrm{OH})$, alkoxyl radical (RO) and peroxyl radical (ROO). Oxygencentred nonradicals are hydrogen peroxide $\left(\mathrm{H}_{2} \mathrm{O}_{2}\right)$ and singlet oxygen $\left(\mathrm{O}_{2}\right)$ (Michalak, 2006). Some of the vegetable and fruit phenols appear to be bound by tight hydrophilic and hydrophobic bonds to the polysaccharides of the plant cell wall (Koley et al., 2010). The degradation of the cell-wall polysaccharides can stimulate the release of these phenolics by enzymecatalysed extraction (Khairil Anuar et al., 2020). Supporting enzymes that have often been used as biocatalysts to obtain target compounds from various plants could increase the efficiency of the extraction, yield and biological activities of polysaccharides (Karaki et al., 2016).

The functions and advantages of natural antioxidants in food and biological systems have received much public concern. This is due to the benefits of natural antioxidants; besides it is safer and healthier than synthetic antioxidant (Chong et al., 2020). Hence, this study aimed to investigate the effects of $\mathrm{pH}$ extraction buffers on antioxidant enzyme activities as well the protein characteristic in water lily. Consequently, the information and data obtained from this study can be a reference for further studies and contribute to the development of new value-added products in the food industry as food ingredients or food supplements.

\section{Materials and methods}

\subsection{Sample preparation}

Water lily (Nymphaeaceae antares) leaves and petiole were harvested from a pond of a private residence situated in Kampung Lorong Bukit, Kuala Terengganu, Malaysia. The plant was identified by Tuan $\mathrm{Hj}$. Mohamad Razali Salam, a plant botanist in the Faculty of Science and Marine Environment (FSSM), Universiti Malaysia Terengganu (Herbarium UNISZA, No: UNISZA0001135). All samples of leaves and petioles of water lily were thoroughly cleaned under running tap water and then drained off on a piece of tissue paper. The cleaned samples were then cut into smaller pieces before undergoing the further process. The chemical substances for analysis purposes are analytical grades such as Tris$\mathrm{HCl}$, Bovine serum albumin, pyrogallol, benzidine, sodium phosphate and standard protein marker were purchased from Sigma-Aldrich, MO, USA.

\subsection{Proximate analysis}

Proximate analysis of the leaves and petioles of water lily was conducted based on the standard procedure of the Association of Official Analytical Chemists (AOAC, 2007). The percentage of moisture, ash, crude protein, crude fat, and crude fibre was evaluated. The percentage of carbohydrates $=100$ (percentage [protein + moisture + crude fat + ash + crude fibre]) was determined as the carbohydrate content. All the analysis was carried out in triplicate.

\subsection{Water lily extraction}

Eight grams of water lily leaves and petioles were washed, cleaned and cut into small cubes separately. Samples were thoroughly homogenized at $4^{\circ} \mathrm{C}$ using a mortar in $70 \mathrm{~mL} 1 \mathrm{M}$ Tris-HCl buffer with 3 different $\mathrm{pH}$ treatments $(\mathrm{pH} 6.8,7.1$ and 7.8). The mortar was surrounded by ice cubes to keep it at a sufficiently low temperature. The homogenates were then centrifuged for 30 mins at $13000 \times g$ at $4^{\circ} \mathrm{C}$ (Gyrozen, Korea). The supernatants were kept at $-40^{\circ} \mathrm{C}$ and used for protein determination, protein characterization and antioxidant enzyme assay.

\subsection{Protein quantification}

The concentration of protein in both leaves and water lily petioles was measured using Bradford (1976) method with bovine serum albumin (BSA) was assigned as standard. The approach is based on a colourimetric assay proportional to the protein binding of the Coomassie blue dye. Each sample was allowed to incubate at room temperature for 20 mins. The absorbance of each sample was measured at $595 \mathrm{~nm}$. The absorbance of each BSA standard was plotted as a function of its theoretical concentration.

\subsection{Thermal characteristics}

Thermal characteristics of protein in water lily's leaves and petioles were examined by differential scanning calorimeter (DSC Q2000, Research Instrument, Switzerland), following the method as described by Mariod et al. (2010) with slight modification. Three microliters of sample were placed in sealed aluminium pans. The scanning temperature was assigned at 30 to $120^{\circ} \mathrm{C}$ with a heating rate of $10^{\circ} \mathrm{C} / \mathrm{min}$. The Indium 
standards were used for temperature and energy calibration. The denaturation temperature and denaturation enthalpy value was determined from each thermogram (Gorinstein et al., 1996).

\subsection{Functional groups}

The functional groups of water lily samples were determined using Fourier-transform infrared spectroscopy (FTIR) (Nicolet iS10, Thermo Scientific, US) in which $5 \mathrm{mg}$ of water lily dried powder was mixed with $250 \mathrm{mg}$ of $\mathrm{KBr}$ (1:50). The mixture was homogenized using an agate mortar and pestle and then was pressed into a pellet (1-2 mm thick films) with a 15ton hydraulic press. The FTIR spectra were then obtained from a wavenumber of 600 to $4000 \mathrm{~cm}^{-1}$ during 64 scans with $2 \mathrm{~cm}^{-1}$ resolutions. The resulting spectrum represents the molecular absorption and transmission, creating a molecular fingerprint of the sample (Zainol et al., 2017).

\subsection{Antioxidant enzyme assays}

\subsubsection{Catalase}

The catalase activity of water lily's leaves and petioles were analysed followed the method by Khairil Anuar et al. (2020). The reaction mixture contains 1.25 $\mathrm{mL}$ of $50 \mathrm{mM}$ sodium phosphate buffer ( $\mathrm{pH} 7), 0.15 \mathrm{~mL}$ of $\mathrm{H}_{2} \mathrm{O}_{2}(0.5 \mathrm{~mL})$ and $0.1 \mathrm{~mL}$ enzyme extract. Blanks contain the same reaction mixture except for enzyme extract. The absorbance of blank was read at $240 \mathrm{~nm}$ followed by samples read for every 5 mins. The catalase activity was measured by decomposition of hydrogen peroxide $\left(\mathrm{H}_{2} \mathrm{O}_{2}\right)$ as determined by a decrease of absorbance at $240 \mathrm{~nm}$.

\subsubsection{Peroxidase activity (POX)}

Peroxidase activity (POX) was determined using the method by Khairil Anuar et al. (2020). The blank consisted of $4 \mathrm{~mL}$ of $0.2 \mathrm{M}$ acetate buffer ( $\mathrm{pH} 4.8$ ), 0.4 $\mathrm{mL} \mathrm{H}_{2} \mathrm{O}_{2}(3 \%)$, and $0.2 \mathrm{~mL} 20 \mathrm{mM}$ benzidine. The assay mixture consisted of $4 \mathrm{~mL}$ of $0.2 \mathrm{M}$ acetate buffer $(\mathrm{pH}$ 4.8), $0.4 \mathrm{~mL}$ of $\mathrm{H}_{2} \mathrm{O}_{2}(3 \%), 0.2 \mathrm{~mL}$ of $20 \mathrm{mM}$ of benzidine and $0.2 \mathrm{~mL}$ of enzyme extract. The increase in absorbance was recorded at $530 \mathrm{~nm}$. POX activity was described as $1 \mu \mathrm{M}$ benzidine oxidised per min per $\mathrm{mg}$ protein (Unit $\mathrm{mg}^{-1}$ ) (protein).

\subsubsection{Polyphenol oxidase activity}

Polyphenol oxidase activity was measured based on the method of $\mathrm{Kim}$ and $\mathrm{Kim}(2013)$ at $40^{\circ} \mathrm{C}$. The reaction mixture consisted of $2.5 \mathrm{~mL}$ of $0.2 \mathrm{M}$ sodium phosphate buffer ( $\mathrm{pH} 6.8$ ), $0.2 \mathrm{~mL}$ of $20 \mathrm{mM}$ pyrogallol and $0.2 \mathrm{~mL}$ of enzyme extract. The absorbance was recorded at 430 and PPO activity was described as $1 \mu \mathrm{M}$ pyrogallol oxidised per min per mg protein (Unit mg-1 (protein)).

\subsubsection{Superoxide dismutase (SOD)}

Superoxide dismutase SOD activity in water lily's leaves and petioles was determined using the method of Kanungo et al. (2015). A reaction mixture consisted of 1 $\mathrm{mL}$ of a formulation $(27 \mathrm{~mL} 50 \mathrm{mM}$ sodium phosphate buffer ( $\mathrm{pH}$ 7.8), $20 \mu \mathrm{L}$ ethylene diamine tetraacetic acid (EDTA), and $1.5 \mathrm{~mL}$ L-methionine), $1 \mathrm{~mL} 75 \mu \mathrm{M}$ nitroblue tetrazolium (NBT), $50 \mu \mathrm{L}$ enzyme extract, and $10 \mu \mathrm{L} 2 \mathrm{mM}$ riboflavin. Blanks consisted of the same reaction mixtures as the sample and the tube was wrapped with aluminium foil to indicate the nonirradiated blank. The negative control reaction mixture was prepared in the same way as the blank except for the omission of enzyme extract and is wrapped with aluminium foil. The reaction mixture was irradiated with light for 10 mins and the absorbance against the nonirradiated blank was recorded at $560 \mathrm{~nm}$. One unit of SOD activity is defined as the amount of enzyme that inhibits $50 \%$ of NBT. SOD activity was calculated by evaluating its ability to inhibit NBT photochemical reduction at $560 \mathrm{~nm}$.

\subsection{Statistical analysis}

Results obtained from the antioxidant enzyme assays were analysed by using the Minitab 14.12.0.0 Statistical Software. The results were expressed as mean \pm standard deviation. The significant difference at $(p<0.05)$ was performed by one-way analysis of variance (ANOVA) and Fisher's Least Significant Difference (LSD) test.

\section{Results and discussion}

\subsection{Proximate composition}

Proximate analysis results of leaves and petioles of water lily are summarised in Table 1. Petioles showed higher moisture content that is $95.27 \pm 0.35 \%$ and significantly different to leaves which contain $88.31 \pm 0.35 \%$ of moisture content. The result is in accordance with the findings by Okoye et al. (2002) who reported that the leaves of water hyacinth (Wichhornia crassipes) had the least moisture content of $85.15 \%$ while the petioles which are constantly in contact with water had the higher water content than leaves that is $91.78 \%$. Since water lily is an aquatic plant, it is expected to contain more water than plants that grow on land. Similarly, the dried leaves showed higher moisture content $(7.74 \pm 0.76 \%)$ than dried petioles $(6.87 \pm 0.57 \%)$. A range of $4-14 \%$ of moisture content in the dried African leafy vegetables was an effective preservation technique to prevent deterioration (Van't Hag et al., 2020). Furthermore, Odewo et al. (2014) quoted that the 
Table 1. Proximate composition of Water lily (N. antares) leaves and petiole

\begin{tabular}{lccccccc}
\hline & \multicolumn{2}{c}{ Moisture content (\%) } & \multirow{2}{*}{ Fat (\%) } & Fibre (\%) & Crude Protein (\%) & Ash (\%) & Carbohydrate $(\%)$ \\
\cline { 2 - 7 } & Fresh & Dried & & & & & \\
\hline Leaves & $88.31 \pm 0.35^{\mathrm{b}}$ & $7.74 \pm 0.76^{\mathrm{a}}$ & $5.24 \pm 0.77^{\mathrm{a}}$ & $13.14 \pm 0.79^{\mathrm{a}}$ & $19.54 \pm 0.72^{\mathrm{a}}$ & $10.05 \pm 1.17^{\mathrm{b}}$ & $44.29 \pm 2.45^{\mathrm{a}}$ \\
Petioles & $95.27 \pm 0.35^{\mathrm{a}}$ & $6.87 \pm 0.57^{\mathrm{a}}$ & $4.18 \pm 0.73^{\mathrm{a}}$ & $12.15 \pm 0.69^{\mathrm{a}}$ & $3.37 \pm 0.14^{\mathrm{b}}$ & $17.26 \pm 1.02^{\mathrm{a}}$ & $56.17 \pm 4.51^{\mathrm{a}}$ \\
\hline
\end{tabular}

Values represent the mean \pm standard deviation. Values with the same superscript within the column are not significantly different $(\mathrm{P}<0.05)$.

moisture content in leaves of water lily's leaves and petal (\% dry weight) was $1.88 \%$, which was lower than the current study. However, it should be noted that moisture content would depend on the degree of drying for dry matter. It was clear that petioles are larger in density, weight and volume than leaves. A higher value of ash content was obtained in the petiole $(17.26 \pm 1.02 \%)$ compared to the leaves $(10.05 \pm 1.17 \%)$. Water lily leaves exhibited a higher crude fat content $(5.24 \pm 0.77 \%)$ compared to petiole $(4.18 \pm 0.73 \%)$ which might be due to the oily nature of the leaves (Tungmunnithum et al., 2020). Water lily leaves also exhibited significantly $(\mathrm{p}<0.05)$ higher crude protein content $(19.54 \pm 0.72 \%)$ compared to the petioles $(3.37 \pm 0.14 \%)$. This study also showed that water lily leaves yielded higher quantities of fibre $(13.14 \pm 0.79 \%)$ than petioles $(12.15 \pm 0.69 \%)$. High fibre in the leaves may be due to the rich in insoluble dietary fibre (Mohammed et al., 2013). Fascinatingly, this study shows that the leaves of the water lily and the petiole contain low fat but high in carbohydrates. Carbohydrate was found to be the greatest in both the leaves and the petiole. The amount of carbohydrate content was consistent with Odewo et al. (2014), which reported the highest components of the plant species.

\subsection{Protein content in water lilies leaves and petioles}

Table 2 shows the leaves with $\mathrm{pH} 7.8$ of extraction buffer had the highest protein concentration that is $17.5 \pm 0.14 \mathrm{mg} / \mathrm{mL}$ while leaves with $\mathrm{pH} 7.1$ of extraction buffer had the lowest amount of protein concentration that is only $8.2 \pm 0.42 \mathrm{mg} / \mathrm{mL}$ and all samples were significantly different $(p<0.05)$ to each other. The yield and properties of protein content are influenced by the extraction process and various factors such as $\mathrm{pH}$, salt concentration, medium ion strength, net charge and electrostatic repulsion (Tan et al., 2011).

Table 2 also reveals that the highest protein concentration was found in petioles subject to $\mathrm{pH} 7.1$ treatment and that the protein concentration was not significantly different from that of petioles with $\mathrm{pH} 6.8$ extraction buffer. In contrast, the lowest protein concentration was found in petioles with $\mathrm{pH} 7.8$ treatment. Hence, both of them were significantly different $(p<0.05)$ to petioles with $\mathrm{pH} 7.8$ of extraction buffer. Based on this study, the protein concentration can be concluded as higher in leaves compared to petioles. The same result was found in water lily from Tatabu (Nigeria), where the crude protein in leaves was higher than petioles that are $19.54 \%$ and $9.04 \%$ respectively (Mohammed et al., 2013).

\subsection{Protein thermal properties}

Differential scanning calorimetry (DSC) determines the calorimetric changes in proteins as a function of temperature. Thermal protein denaturation is due to the rupture of intramolecular hydrogen bonds (Chen and Oakley, 1995; Cordella et al., 2003). Denaturation temperatures are measurements of protein thermal stability. Their determination under controlled conditions should provide a specific comparison of the different proteins' thermal stability. Data from DSC measurements of leaves at pH 6.8 extraction buffer is shown in Figure 1. The leaves extract had denaturation temperatures at $81.84^{\circ} \mathrm{C}$. Mariod et al. (2010), reported that the thermal denaturation of V36 protein concentrates of defatted kenaf seed is at $81.8^{\circ} \mathrm{C}$. This result is similar to the present study. Protein enthalpy modifications may be used to predict the degree of protein denaturation (Corkrey et al., 2014). The protein is heated at a constant rate in DSC and the thermal denaturation-related heat shift is evident. In the type of heat that determines an endothermic phase, the process absorbs energy from the surroundings. Due to heat denaturation, the amount of heat absorbed is determined by DSC in the form of enthalpy unfolding. The improvement in enthalpy was calculated when all of the protein crystallised $(100 \%$ crystallization). Due to the unfolding of the protein, the property of crystallinity is linked to enthalpy. The protein will crystallize more rapidly when the protein absorbs more energy (Li et al., 2008). The present study shows the glass transition $\left(\mathrm{T}_{\mathrm{g}}\right)$ of the leaves sample is at $81.84^{\circ} \mathrm{C}$ and the enthalpy $(\Delta \mathrm{H})$ value is very low that is

Table 2. Protein concentration $(\mathrm{mg} / \mathrm{mL})$ of water lily's leaves and petioles with different $\mathrm{pH}$ of extraction buffer.

\begin{tabular}{ccccccc}
\hline $\mathrm{pH}$ of extraction buffer & Leaves pH 6.8 & Leaves pH 7.1 & Leaves pH 7.8 & Petioles pH 6.8 & Petioles pH 7.1 & Petioles pH 7.8 \\
\hline Protein & $12.5 \pm 0.42^{\mathrm{b}}$ & $8.20 \pm 0.42^{\mathrm{c}}$ & $17.50 \pm 0.14^{\mathrm{a}}$ & $1.60 \pm 0.14^{\mathrm{d}}$ & $2.10 \pm 0.07^{\mathrm{d}}$ & $1.00 \pm 0.14^{\mathrm{d}}$ \\
\hline
\end{tabular}

Values represent the mean \pm standard deviation. Values with the same superscript within the row are not significantly different $(\mathrm{P}<0.05)$. 
$0.001426 \mathrm{~J} / \mathrm{g}$. Ross and Karel (1991) suggested that glass transition temperature $(\mathrm{Tg})$ is closely correlated with protein stability, which depends on storage conditions such as water activity, humidity and temperature. Hence, the $T_{g}$ can be set as a reference parameter to characterize the properties, quality, stability and safety of the food systems. Figure 2 shows the comparison between thermograms of leaves and petioles samples.

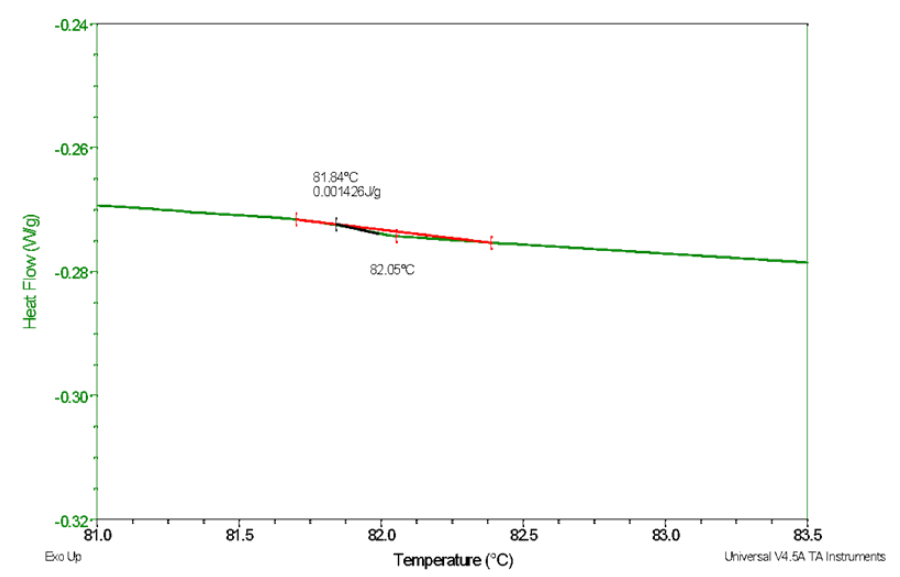

Figure 1. Differential scanning calorimetry (DSC) measurements for leaves extract at $\mathrm{pH} 6.8$ of extraction buffer.

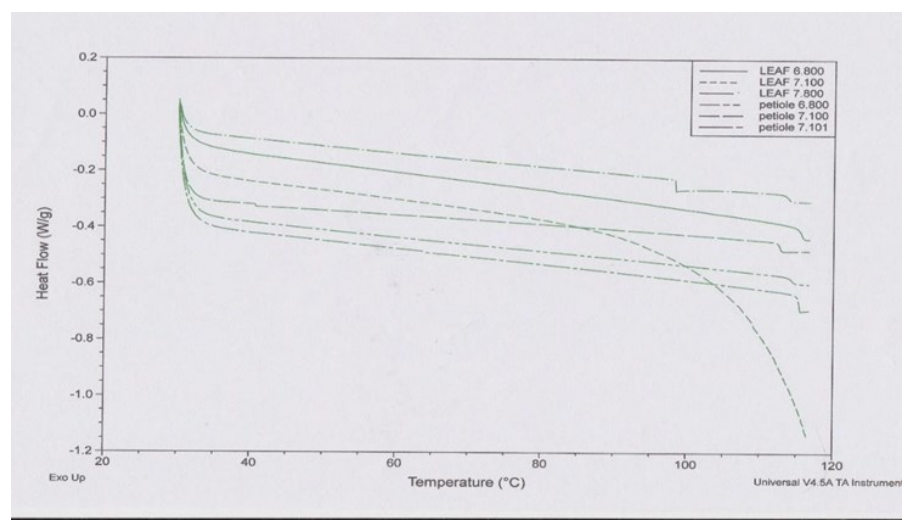

Figure 2. The comparison of thermograms of leaves and petioles samples.

\subsection{Functional groups}

Table 3 displays the effects of FTIR peak values and functional groups, and Figures 3 and 4 show the FTIR spectrum profile. The FTIR spectrum confirmed the presence of phenol and alcohol, alkyne, amide, ether and aromatic compounds in leaves and petioles of water lily. The peak values obtained for all leaves samples of the extraction buffer are somewhat similar. The more intense band occurring at $3385.95 \mathrm{~cm}^{-1}, 2112.42 \mathrm{~cm}^{-1}, 2357.38$ $\mathrm{cm}^{-1}, 1644.52 \mathrm{~cm}^{1}, 1066.06 \mathrm{~cm}^{-1}$, and $726.60 \mathrm{~cm}^{-1}$ corresponding to $\mathrm{O}-\mathrm{H} / \mathrm{C} \equiv \mathrm{C} / \mathrm{C}=\mathrm{O} / \mathrm{C}-\mathrm{O} / \mathrm{C}-\mathrm{H}$ stretching and bending respectively indicate the presence of alcohol, alkyne, amide, ether and aromatic compounds in leaves of water lily (Figure 4). There was not much difference between the peak values obtained from leaves and petioles samples. The more intense band occurred at $3385.77 \mathrm{~cm}^{-1}, 2123.13 \mathrm{~cm}^{-1}, 1644.69 \mathrm{~cm}^{-1}$ and $726.55 \mathrm{~cm}$ ${ }^{-1}$ corresponding to $\mathrm{O}-\mathrm{H} / \mathrm{C} \equiv \mathrm{C} / \mathrm{C}=\mathrm{O} / / \mathrm{C}-\mathrm{H}$ stretching and bending respectively indicate the presence of alcohol, alkyne, amide, and aromatic compounds in petioles of water lily. The difference in functional groups present in petioles compared to leaves is the absence of ether in petioles. According to the match results for functional groups present in leaves samples by FTIR library, the highest match for leaves was $67.68 \%$ and $52.37 \%$ of water, deuterium-depleted and D-Ribulose respectively. A similar match is also found in petioles with the highest match as $68.07 \%$ water, deuterium-depleted. The phenol and alcohol group found in this study is according to the findings of Ashokkumar and Ramaswamy, (2014) which reported that methanol extract of Phyllanthus amarus leaves showed characteristic absorption bands at 3385 $\mathrm{cm}^{-1}$ for a hydroxyl (-OH) group. There is no absorbance in between the region $2220-2260 \mathrm{~cm}^{-1}$ indicating that there are no cyanide groups in all the extracts of the medicinal plants taken. This shows that samples taken for the study do not contain any toxic substances (Ragavendran et al., 2011). The very strong absorption band observed at approximately $3373-3422 \mathrm{~cm}^{-1}$ may be due to the presence of bonded N-H/C-H/O-H stretching of amines and amides (Liew et al., 2020).

\subsection{Effect of $p H$ extraction buffer on enzymatic antioxidant activities}

\subsubsection{Catalase}

Table 4 shows that the leaves sample with $\mathrm{pH} 6.8$ and 7.1 of extraction buffer possessed similar catalase activity, which is $0.03 \mathrm{U} / \mathrm{mg}$ protein. However, all

Table 3. FTIR spectral peak values and functional groups obtained for the leaves and petioles

\begin{tabular}{ccccc}
\hline Sample & Peak no & Wavelength $\left(\mathrm{cm}^{-1}\right)$ & Functional group & Mode of vibration \\
\hline \multirow{6}{*}{ Leaves } & 1 & 3385.95 & Phenol and alcohol O-H & stretch \\
& 2 & 2112.42 & Alkynes C $\equiv \mathrm{C}$ & stretch \\
& 3 & 1644.52 & Amide C $=\mathrm{O}$ & stretch \\
& 5 & 1066.06 & Ether C-O & stretch \\
Petioles & 2 & 726.6 & Aromatic C-H & Bend \\
& 3 & 3385.75 & Phenol and alcohol O-H & stretch \\
& 3 & 2123.13 & Alkynes C $\equiv \mathrm{C}$ & stretch \\
& 4 & 1644.69 & Amide C $=\mathrm{O}$ & stretch \\
\hline
\end{tabular}




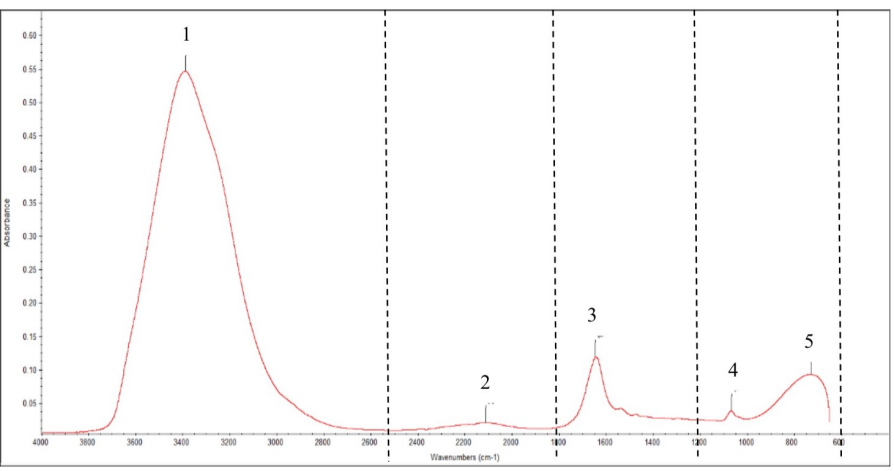

Figure 3. FTIR spectrum profile of water lily's leaves. $1=$ Phenol and alcohol O-H, $2=$ Alkynes $\mathrm{C} \equiv \mathrm{C}, 3=$ Amide $\mathrm{C}=$ $\mathrm{O}, 4=$ Ether $\mathrm{C}-\mathrm{O}, 5$ = Aromatic $\mathrm{C}-\mathrm{H}$

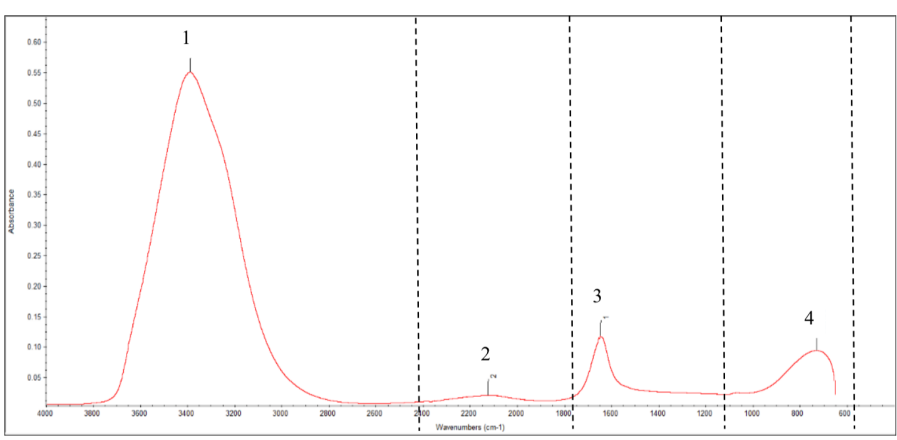

Figure 4. FTIR spectrum profile of water lily's petioles. $1=$ Phenol and alcohol O-H, 2 = Alkynes $\mathrm{C} \equiv \mathrm{C}, 3=$ Amide $\mathrm{C}=$ $\mathrm{O}, 4=$ Aromatic $\mathrm{C}-\mathrm{H}$.

Table 4. Superoxide dismutase activity, polyphenol oxidase activity, catalase $\mathrm{H}_{2} \mathrm{O}_{2}$ radical inhibition, and peroxidase activity water lily's leaves and petioles extraction at different $\mathrm{pH}$ conditions.

\begin{tabular}{cccccc}
\hline $\begin{array}{c}\mathrm{pH} \\
\text { conditions }\end{array}$ & $\begin{array}{c}\text { Sample } \\
\text { part }\end{array}$ & $\begin{array}{c}\text { Superoxide dismutase } \\
\text { activity }(\mathrm{m} / \mathrm{mg})\end{array}$ & $\begin{array}{c}\text { Polyphenol oxidase } \\
\text { activity }(\mathrm{U} / \mathrm{mg})\end{array}$ & $\begin{array}{c}\text { Catalase } \mathrm{H}_{2} \mathrm{O}_{2} \text { radical } \\
\text { inhibition }(\%)\end{array}$ & $\begin{array}{c}\text { Peroxidase activity } \\
(\mathrm{U} / \mathrm{mg})\end{array}$ \\
\hline \multirow{2}{*}{$\mathrm{pH} 6.8$} & Leaves & $4.40 \pm 2.26^{\mathrm{a}}$ & $0.11 \pm 0.01^{\mathrm{b}}$ & $0.03 \pm 0.028^{\mathrm{a}}$ & $0.001 \pm 0.001^{\mathrm{a}}$ \\
& Petioles & $8.45 \pm 8.27^{\mathrm{a}}$ & $1.50 \pm 0.21^{\mathrm{b}}$ & $0.007 \pm 0.007^{\mathrm{a}}$ & $0.001 \pm 0.0003^{\mathrm{b}}$ \\
\hline \multirow{2}{*}{$\mathrm{pH} \mathrm{7.1}$} & Leaves & $2.65 \pm 0.92^{\mathrm{a}}$ & $0.30 \pm 0.01^{\mathrm{a}}$ & $0.03 \pm 0.014^{\mathrm{a}}$ & $0.001 \pm 0.0007^{\mathrm{a}}$ \\
& Petioles & $6.10 \pm 3.11^{\mathrm{a}}$ & $0.70 \pm 0.01^{\mathrm{b}}$ & $0.003 \pm 0.001^{\mathrm{a}}$ & $0.01 \pm 0.001^{\mathrm{a}}$ \\
\hline \multirow{2}{*}{$\mathrm{pH} \mathrm{7.8}$} & Leaves & $3.50 \pm 0.71^{\mathrm{a}}$ & $0.07 \pm 0.01^{\mathrm{c}}$ & $0.001 \pm 0.00^{\mathrm{a}}$ & $0.003 \pm 0.001^{\mathrm{a}}$ \\
& Petioles & $4.90 \pm 3.39^{\mathrm{a}}$ & $2.41 \pm 0.15^{\mathrm{a}}$ & $0.03 \pm 0.02^{\mathrm{a}}$ & $0.0003 \pm 0.000^{\mathrm{b}}$ \\
\hline
\end{tabular}

Values represent the mean \pm standard deviation. Values with the same superscript within the column are not significantly different $(\mathrm{P}<0.05)$.

samples of leaves in $\mathrm{pH} 6.8, \mathrm{pH} 7.1$ and $\mathrm{pH} 7.8$ of the extraction buffer showed no significant difference $(p>0.05)$ among each other. There are many factors that can affect an enzyme's activity. These factors are generally referred to as effectors. Examples of effectors are temperature, $\mathrm{pH}$, inhibitors, and activators. Effectors such as temperature and $\mathrm{pH}$ generally affect the noncovalent interactions that occur in an enzyme's structure. This result might be caused by the range of extraction $\mathrm{pH}$ used, which already falls in the optimum $\mathrm{pH}$ range for the enzyme. Most enzymes are active in the $\mathrm{pH}$ range of 6 to 8 , yet some enzymes can function at a $\mathrm{pH}$ as low as 3 and as high as 10 (Robinson, 2015).

Catalase (CAT) is one of the major antioxidant enzymes and efficiently scavenges $\mathrm{H}_{2} \mathrm{O}_{2}$ and does not require a reducing substrate to perform the task (Kumari et al., 2006). The highest activity of catalase was found in petioles with $\mathrm{pH} 7.8$ of extraction buffer that is 0.033 $\pm 0.03 \mathrm{U} / \mathrm{mg}$ protein, as shown in Table 1 . However, all samples of petioles with $\mathrm{pH} 6.8, \mathrm{pH} 7.1$ and $\mathrm{pH} 7.8$ of extraction buffer showed no significant difference $(p>0.05)$ among each other. The result from this present study can be supported by Arabaci and Usloqlu (2013), which stated that the effect of $\mathrm{pH}$ on the free and immobilized enzyme for $\mathrm{H}_{2} \mathrm{O}_{2}$ degradation was investigated in the $\mathrm{pH}$ range between 3 and 9 in acetate or/and phosphate buffers at $25^{\circ} \mathrm{C}$. Finally, the activity measurements of the enzymes were made under the optimum assay conditions and resulted in similarities of $\mathrm{pH}$ stabilities for both enzymes. Both free and immobilized catalase gave an optimum at $\mathrm{pH}$ 7.5. However, the immobilized catalase showed much broader $\mathrm{pH}$ stability than the free enzyme. This suggested that immobilized enzyme was less sensitive to $\mathrm{pH}$ changes than free enzyme.

\subsubsection{Peroxidase value (POX)}

Peroxidase enzymes are widely distributed in plants and animals, including bacteria, to protect cells against the effects of oxidative stress and cell damage due to hydrogen peroxide. Table 4 shows the activity of peroxidase in water lily's leaves with different $\mathrm{pH}$ of extraction buffer. All samples of leaves with $\mathrm{pH} 6.8, \mathrm{pH}$ 7.1 and $\mathrm{pH} 7.8$ of the extraction buffer showed no significant difference $(p>0.05)$ among each other. The highest peroxidase activity was possessed by leaves of $\mathrm{pH} 7.8$ extraction buffer that is $0.003 \mathrm{U} / \mathrm{mg}$. Saeidian and Ghasemifar, (2013) reported that $\mathrm{pH}$ is a determining factor in the expression of enzymatic activity in Pyrus communis. It alters the ionization states of amino acid side chains or substrates. For peroxidase activity, one $\mathrm{pH}$ optimum was observed at 6.5 and no activity was detectable at $\mathrm{pH} 3$ and 9, regardless of the condition. Other than that, Kumar et al. (2008) reported that Ricinus peroxidases showed the maximum percent relative activity at $\mathrm{pH} 5$ and it decreased when $\mathrm{pH}$ 
increased. Dubey et al. (2007) has also shown a similar acidic $\mathrm{pH}$ ranging from $\mathrm{pH} 5$ to $\mathrm{pH} 7$ in four varieties of apple peroxidases. Optimal levels of peroxidase have also been reported from various vegetable sources (Vamos-Vigyazo and Haard 2009), apoplastic peroxidases from various plants (Hendriks et al., 1991; Nair and Showalter, 1996) at different acidic pH and Cassia didymobotrya peroxidase at $\mathrm{pH} 5.5$ (Vitali et al., 1998). The estimation of secondary structural elements at different $\mathrm{pH}$ values suggested a maximum reduction of beta-strands and beta-turns at $\mathrm{pH} 5.5$, which resulted in further exposure of the heme to the solvent and improved the overall conformational flexibility of the protein (Kamal et al., 2003). These findings were contrary to the present study due to the different samples and conditions used.

Peroxidase activity (POX) is considered a general response to oxidative stress, such as salinity stress in the examined plant species (Jaleel et al., 2009). POXs are involved in $\mathrm{H}_{2} \mathrm{O}_{2}$ scavenging, so their activity could decrease the oxidative stress caused by $\mathrm{NaCl}$ treatment. In addition, Ylldiz (2019) reported that the rate of enzymatic browning in fruit and vegetables is dictated by the active polyphenol oxidase and peroxidase content of the tissues, the phenolic content of the tissues, $\mathrm{pH}$, temperature, and the availability of oxygen to the tissues. Petioles with $\mathrm{pH} 7.1$ of extraction buffer showed the highest peroxidase activity that is $0.006 \pm 0.00 \mathrm{U} / \mathrm{mg}$ and significantly different $(\mathrm{p}<0.05)$ to leaves with $\mathrm{pH} 6.8$ and pH 7.8 of extraction buffer. This highest POX activity was linear to the highest protein concentration of petioles with a pH 7.1 extraction buffer. Khairil Anuar et al. (2020) reported that all peroxidase activities measured at their optimal $\mathrm{pH}$ showed a linear increase in activity with increasing protein concentration, suggesting that there were no effects of inhibitors or effectors within the supernatants.

\subsubsection{Polyphenol oxidase (PPO)}

Table 4 shows the activity of polyphenol oxidase activity (PPO) in water lily's leaves and petioles extracted in different $\mathrm{pH}$ of extraction buffers. Leaves extracted in $\mathrm{pH} 7.1$ buffer exhibited significantly $(p<0.05)$ the highest polyphenol oxidase activity than that of leaves with $\mathrm{pH} 6.8$ and $\mathrm{pH} 7.8$ extraction buffer. Table 4 also revealed that petioles extracted in $\mathrm{pH} 7.8$ extraction buffer showed the highest PPO $(2.41 \pm 0.15 \mathrm{U} /$ $\mathrm{mg}$ ) than that of petiole samples extracted in $\mathrm{pH} 6.8$ and pH 7.1 of extraction buffer. Similarly, Derahman et al. (2017) reported that $\mathrm{pH} 8$ (which was similar to $\mathrm{pH}$ 7.8) was suitable for extraction as the PPO showed the best results. Polyphenol oxidase catalyses two basic reactions that are o-position hydroxylation adjacent to the current phenolic substrate hydroxyl group (monophenol oxidase activity) and o-benzoquinone diphenol oxidation (diphenol oxidase activity). As a co-substrate, both reactions use molecular oxygen. It is still uncertain whether a single enzyme system experiences both monoand di- phenol oxidase activities. However, the ratio of monophenol to diphenol oxidase activity is typically $1: 10$ or as low as 1:40 when both monophenol and diphenol oxidases are present in plants (Toledo and Aguirre, 2016). PPO optimum $\mathrm{pH}$ from some sources has also been reported to occur in the range of $\mathrm{pH} 6$ to $\mathrm{pH} 8$. Maximum PPO activity at $\mathrm{pH} 7$ comparable to this study was observed in d'Anjou pears (Tuncay and Yagar (2011), cocoa beans (Lee et al., 1991), oil bean seeds (Onyebuchi, 2012). Other than that, a similar result was also found in the study done by Mizobutsi et al. (2010) which cited that the activity of polyphenol oxidase in litchi pericarp was maximum at $\mathrm{pH}$ 7.0. Sellés-Marchart et al. (2006) reported that differences in optimum $\mathrm{pH}$ for PPO activity depended on the plant sources, extraction methods, and purity of the enzyme, buffers, and substrates. Conformational changes in the enzyme under alkaline conditions have been due to the rapid deactivation of the enzyme at $\mathrm{pH}$ greater than 8 or the enzyme can react more quickly with o-quinone through the Maillard reaction and or Strecker degradation (converts alpha-amino acids into aldehydes) (Lee et al., 1991). Saeidian and Ghasemifar (2013) reported that polyphenol oxidase activity in Solanum lycopersicum extract was tested at different $\mathrm{pHs}$ ranging from $\mathrm{pH} 2$ to $\mathrm{pH} 10$, using cathecol and pyrogallol as a medium for green and ripe small cherry tomatoes.

\subsubsection{Superoxide dismutase}

Table 4 also illustrates the SOD activity in leaves and petioles of water lily with different extraction buffers respectively. The data clearly showed that leaves with $\mathrm{pH} 6.8$ of extraction buffer showed the highest SOD activity that is $4.40 \pm 2.26 \mathrm{U} / \mathrm{mL}$ while leaves with $\mathrm{pH} 7.8$ of extraction buffer showed the lowest SOD activity that is $2.70 \pm 0.92 \mathrm{U} / \mathrm{mL}$. The highest SOD activity was found in petioles with $\mathrm{pH} 6.8$ of extraction buffer and this result was linear to leaves sample that is $8.45 \pm 8.27 \mathrm{U} /$ $\mathrm{mL}$ while petioles with $\mathrm{pH} 7.8$ of extraction buffer showed the lowest SOD activity that is $4.9 \pm 3.39 \mathrm{U} / \mathrm{mL}$. SOD activity was estimated by measuring its ability to inhibit the photochemical reduction of NBT at $560 \mathrm{~nm}$.

\section{Conclusion}

The study revealed that the $\mathrm{pH} 7.1$ extraction buffer showed a higher protein concentration of water lily's leaves and there was no significance in petioles. In determining the protein characterization, DSC showed 
that the glass transition $\left(\mathrm{T}_{\mathrm{g}}\right)$ of the leaves sample was at $81.84^{\circ} \mathrm{C}$ and the enthalpy $(\Delta \mathrm{H})$ value is very low that is $0.001426 \mathrm{~J} / \mathrm{g}$. Other than that, the functional properties found by FTIR are $\mathrm{O}-\mathrm{H} / \mathrm{C} \equiv \mathrm{C} / \mathrm{C}=\mathrm{O} / \mathrm{C}-\mathrm{O} / \mathrm{C}-\mathrm{H}$ stretching and bending respectively indicate the presence of alcohol, alkyne, amide, ether and aromatic compounds in leaves of water lily while $\mathrm{O}-\mathrm{H} / \mathrm{C} \equiv \mathrm{C} / \mathrm{C}=\mathrm{O} / / \mathrm{C}-\mathrm{H}$ stretching and bending respectively indicate the presence of alcohol, alkyne, amide, and aromatic compounds in petioles of water lily. Finally, in antioxidant enzyme assays, there was only PPO activity which was higher and significant in leaves with $\mathrm{pH} 7.1$ of extraction buffer whereas, in petioles, POX and PPO activity were significant in petioles with $\mathrm{pH} 7.1$ and 7.8 of extraction buffer respectively. From this research, it was found that $\mathrm{pH} 6.8,7.1$ and 7.8 of Tris buffer did not significantly affect antioxidant enzyme activities.

\section{Conflict of interest}

The authors declare that they have no conflict of interest.

\section{Acknowledgement}

This research was funded by UMT short-term grant (Research Incentive Grants /GGP (UMT / RMIC/22/2/25/6(73). The authors would like to thank the Faculty of Fisheries and Food Sciences (FPSM) as well as UMT Research and Field Service Centre for the facilities to conduct this study.

\section{References}

Akinjogunla, O.J., Yah, C.S., Eghafona, N.O. and Ogbemudia, F.O. (2010). Antibacterial activity of leave extracts of Nymphaea lotus (Nymphaeaceae) on Methicillin resistant Staphylococcus aureus (MRSA) and Vancomycin resistant Staphylococcus aureus (VRSA) isolated from clinical samples. Annals of Biological Research, 1(2), 174-184.

Afolayan, A.J., Olubunmi, J.S. and Mutiu, I.K. (2013). Phytochemical analysis and in vitro antioxidant activity of Nymphaea lotus L. International Journal of Pharmacology, 9(5), 297-304. https:// doi.org/10.3923/ijp.2013.297.304.

AOAC. (2007). Official Methods of Analysis of AOAC International. AOAC Official Method 990.26. 17th ed. Gaithersburg, MD, USA: AOAC International.

Arabaci, G. and Usluoglu, A. (2013). Catalytic properties and immobilization studies of catalase from Malva sylvestris L. Journal of Chemistry, 2013, 686185. http://dx.doi.org/10.1155/2013/686185.

Ashokkumar, R. and Ramaswamy, M. (2014). Phytochemical screening by FTIR spectroscopic analysis of leaf extracts of selected Indian medicinal plants. International Journal of Curricular Microbiology Applied Science, 3(1), 395-406. http:// dx.doi.org/10.1155/2013/686185 .

Bradford, M.M. (1976). A rapid and sensitive method for the quantitation of microgram quantities of protein utilizing the principle of protein-dye binding. Analytical Biochemistry, 72(1-2), 248-254. https:// doi.org/10.1016/0003-2697(76)90527-3.

Chen, T. and Oakley, D.M. (1995). Thermal analysis of proteins of pharmaceutical interest. Thermochimica Acta, 248, 229-244. https://doi.org/10.1016/00406031(94)01892-k.

Chen, F., Liu, X., Yu, C., Chen, Y., Tang, H. and Zhang, L. (2017). Water lily as emerging models for Darwin's abominable mystery. Horticulture Research, 4, 17051. https://doi.org/10.1038/ hortres.2017.51.

Chong, K.H., Majid, N.I., Zainol, M.K.M., Mohamad, H. and Mohd Zin, Z. (2018) Preliminary phytochemical screening and effect of hot water extraction conditions on phenolic contents and antioxidant capacities of Morinda citrifolia leaf. Malaysian Applied Biology, 47(4), 1-12.

Chong, K.H., Majid, N.I., Mohd Yusof, H., Zainol, M.K., Mohamad, H. and Mohd Zin, Z. (2020). Catechin profile and hypolipidemic activity of Morinda citrifolia leaf water extract. Helliyon, 6(6), e04337.

https://doi.org/10.1016/ j.heliyon.2020.e04337.

Cordella, C., Faucon, J.P., Cabrol-Bass, D. and Sbirrazzuoli, N. (2003). Application of DSC as a tool for honey floral species characterization and adulteration detection. Journal of Thermal Analysis and Calorimetry, 71(1), 279-290. http:// doi.org/10.1023/a:1022251208688.

Corkrey, R., McMeekin, T.A., Bowman, J.P., Ratkowsky, D.A., Olley, J. and Ross, T. (2014). Protein thermodynamics can be predicted directly from biological growth rates. PLoS ONE, 9(5), e96100.

https://doi.org/10.1371/ journal.pone.0096100.

Crane, P.R. and Friis, E.M. (2020). Water lily, loss of woodiness, and model systems. Proceedings of the National Academy of Sciences, 117(18), 202005075. https://doi.org/10.1073/pnas.2005075117.

Derahman, Z., Mohd Borkhan, N.A., Abdullah Razali, R.F. and Manikam, R.V (2017). The effect of blanching treatment on chemical and sensory properties of Broccoli. International Journal of Advances in Science Engineering and Technology, 5 (4), 56-62.

Dian-Nashiela, F., Noriham, A., Nooraain, H. and 
Azizah, A.H. (2015). Antioxidant activity of herbal tea prepared from Cosmos caudatus leaves at different maturity stages. International Food Research Journal, 22(3), 1189-1194.

Dodamani, S.S., Sanakal, R.D. and Kaliwal, B.B. (2012). Antidiabetic efficacy of ethanolic leaf extract of Nymphaea odorata in alloxan induced diabetic mice. International Journal of Pharmacy and Pharmaceutical Sciences, 4(2), 338-341.

Dubey, A., Diwakar, S.K., Rawat, S.K., Kumar, P., Batra, N., Joshi, A. and Singh J. (2007). Characterization of ionically bound peroxidases from apple (Mallus pumilus) fruits. Preparative Biochemistry and Biotechnology, 37(1), 47-58. https://doi.org/10.1080/10826060601040871.

Mizobutsi, G.P., Finger, F.L., Ribeiro, R.A., Puschmann, R., Neves, L.L.D.M. and Mota, W.F.D. (2010). Effect of $\mathrm{pH}$ and temperature on peroxidase and polyphenoloxidase activities of litchi pericarp. Scientia Agricola, 67(2), 213-217. http:// dx.doi.org/10.1590/S0103-90162010000200013.

Gorinstein, S., Zemser, M., Friedman, M., Rodrigues, W.A., Martins, P.S., Vello, N.A., Tosello, G.A. and Paredes-López, O. (1996). Physicochemical characterization of the structural stability of some plant globulins. Food Chemistry, 56(2), 131-138. https://doi.org/10.1016/0308-8146(95)00144-1.

Hendriks, T., Wijsman, H.J.W. and Loon, L.C. (1991). Petunia peroxidase a: isolation, purification and characteristics. European Journal of Biochemistry, 199(1), 139-146. https://doi.org/10.1111/j.14321033.1991.tb16101.x.

Jaleel, C.A., Riadh, K., Gopi, R., Manivannan, P., Inés, J., Al-Juburi, H.J., Zhao, C.X., Shao, H.B. and Panneerselvam, R. (2009). Antioxidant defense responses: Physiological plasticity in higher plants under abiotic constraints. Acta Physiologia Plantarum, 31(3), 427-436. https://doi.org/10.1007/ s11738-009-0275-6.

Kamal, J.K.A. and Behere, D.V. (2003). Activity, stability and conformational flexibility of seed coat soybean peroxidase. Journal of Inorganic Biochemistry, 94(3), 236-242. https:// doi.org/10.1016/s0162-0134(03)00004-7.

Kanungo, S., Kumari, M. and Sahoo, S.L. (2015). Application of antioxidant enzyme activity and biochemical characterization in static and suspension cultures of Withania somnifera L. towards food technology. Applied Food Biotechnology, 2(2), 15 22. https://doi.org/10.22037/afb.v2i2.7483.

Khairil Anuar, M., Mohd Zin, Z., Juhari, N.H., Hasmadi, M., Smedley, K.L. and Zainol, K. (2020). Influence of pectinase-assisted extraction time on the antioxidant capacity of Spent Coffee Ground (SCG). Food Research, 4(6), 2054 - 2061. https:// doi.org/10.26656/fr.2017.4(6).270.

Karaki, N., Aljawish, A., Humeau, C., Muniglia, L. and Jasniewski, J. (2016). Enzymatic modification of polysaccharides: Mechanisms, properties, and potential applications: A review. Enzyme and Microbial Technology, 90, 1-18. https:// doi.org/10.1016/j.enzmictec.2016.04.004.

Kim, J.-J. and Kim, W.-Y. (2013). Purification and characterization of polyphenol oxidase from fresh ginseng. Journal of Ginseng Research, 37(1), 117123. https://doi.org/10.5142/jgr.2013.37.117.

Knight, S., Hauxwell, J. and Haber, E.A. (2014). Distribution and abundance of aquatic plants - human impacts. Reference Module in Earth Systems and Environmental Sciences. Elsevier Online E-Book. https://doi.org/10.1016/b978-0-12409548-9.09102-8 .

Koley, T.K., Walia, S., Nath, P., Awasthi, O.P. and Kaur, C. (2010). Nutraceutical composition of Zizyphus mauritiana Lamk (Indianber): effect of enzyme-assisted processing. International Journal of Food Sciences and Nutrition, 62(3), 276-279. https://doi.org/10.3109/09637486.2010.526930.

Kumar, P., KamLe, M., Singh, J. and Rao, D.P. (2008). Isolation and characterization of peroxidase from the leaves of Ricinus communis. International Journal of Biotechnology and Biochemistry, 4(4), 282-292.

Kumari, G.J., Reddy, A.M., Naik, S.T., Kumar, S.G., Prashanthi, J., Sriranganayakulu, G., Reddy, P.C. and Sudhakar, C. (2006). Jasmonic acid induced changes in protein pattern, antioxidative activities and peroxidase isozymes in peanut seedlings. Biological Plantarum, 50(2), 219-226. https:// doi.org/10.1007/s10535-006-0010-8.

Lacoul, P. and Freedman, B. (2006). Environmental influences on aquatic plants in freshwater ecosystems. Environmental Reviews, 14(2), 89-136. https://doi.org/10.1139/A06-001.

Lee, P.M., Lee, K.-H., Ismail, M. and Karim, A. (1991). Biochemical studies of cocoa bean polyphenol oxidase. Journal of the Science of Food and Agriculture, 55(2), 251- 260. https:// doi.org/10.1002/jsfa.2740550210.

Les, D.H. (2002). Nymphaeles. Encyclopedia of Life Sciences. USA: John Wiley and Sons, Ltd.

Li, C., Guocheng, D., Dongxu, Z. and Jian, C. (2008). Thermal stability and conformational changes of transglutaminase from a newly isolated Streptomyces hygroscopicus. Bioresource Technology, 99(9), 3794 
-3800 .

https://doi.org/10.1016/

j.biortech.2007.07.017.

Liew, S.Y., Mohd Zin, Z., Mohd Maidin, N.M., Mamat, H. and Zainol, M.K. (2020). Effect of the different encapsulation methods on the physicochemical and biological properties of Clitoria ternatea flowers microencapsulated in gelatine. Food Research, 4(4), 1098-1108.

https://doi.org/10.26656/fr.2017.4 (4).033.

Mariod, A.A., Fathy, S.F. and Ismail, M. (2010). Preparation and characterisation of protein concentrates from defatted kenaf seed. Food Chemistry, 123(3), 747-752. https://doi.org/10.1016/ j.foodchem.2010.05.045.

Michalak, A. (2006). Phenolic compounds and their antioxidant activity in plants growing under heavy metal stress. Polish Journal of Environmental Study, 15(4), 523-530.

Mohammed, H.A., Uka, U.N. and Yauri, Y.A.B. (2013). Evaluation of nutritional composition of water lily (Nymphaea lotus linn.) from Tatabu flood plain, north-central, Nigeria. Journal of Fisheries and Aquatic Science, 8(1), 261-264. https:// doi.org/10.3923/jfas.2013.261.264.

Nair, A.R. and Showalter, A.M. (1996). Purification and characterization of a wound inducible cellm wall cationic peroxidase from carrot. Biochemistry, Biophysics Research Communication, 226(1), 254260.

Odewo, S.A., Agbeja, A.O., Olaifa, K.A., Ojo, A.P. and Ogundana S.A. (2014). Proximate and spectroscopic analysis of Passiflora foetida L. International Journal of Scientific and Technology Research, 3(9), 353-356.

Ogbadoyi, E.O., Abdulganity, A.O, Adama, T.Z. and Okogun, J.I. (2007) In vivo trypanocidal activity of Annonasenegalensis Pers. leaf extract against Trypanosoma brucei brucei. Journal of Ethnopharmacology, 112(1), 85-89. https:// doi.org/10.1016/j.jep.2007.02.015.

Okoye, P.C., Daddy, F. and Jlesanmj. B.D. (2002). The nutritive value of water hyacinth (Wichhornia crassipes) and its utilization in fish feed, presented at the International Conference on Water Hyacinth, New Bussa, 2014. Nigeria, National Institute for Freshwater Fisheries Research, Nigeria.

Onyebuchi, S.O. (2012). Kinetic analysis of the thermostability of peroxidase from African oil bean (Pentaclethra macrophylla Benth) seeds. Journal of Biochemical Technology, 4(1), 459-463.

Pareek, A. and Kumar, A. (2016). Pharmocognostic studies on Nymphaea spp. World Journal of
Pharmaceutical Research, 5(6), 6285. https:// doi.org/10.20959/wjpr20166-6285.

Ragavendran, P., Sophia, D., Raj, A.C. and Gopalakrishnan, V.K. (2011). Functional group analysis of various extracts of Aerva lanata by FTIR spectrum. Pharmacology Online, 1, 358-364.

Robinson, P.K. (2015). Enzymes: principles and biotechnological applications. Essays in Biochemistry, 59, 1-41. https://doi.org/10.1042/ bse 0590001.

Ross, Y. and Karel, M. (1991). Applying state diagrams to food processing and development. Food Technology, 45(12), 66-71.

Saeidian, S. and Ghasemifar, E. (2013). Effect of temperature on guaiacol Peroxidase of Pyrus communis. International Letters of Natural Sciences, 5, 46-51. https://doi.org/10.18052/ WwW.scipress.com/ILNS.5.46.

Sellés-Marchart, S., Casado-Vela, J. and Bru-martinez, R. (2006). Isolation of a latent polyphenol oxidase from loquat fruit (Eriobotrya japonica Lindl.) kinetic characterization and comparison with the active form. Archives of Biochemistry and Biophysics, 446 (2), 175-185. https://doi.org/10.1016/ j.abb.2005.12.004.

Tan, S.H., Mailer, R.J., Blanchard, C.L. and Agboola, S.O. (2011). Canola proteins for human consumption: Extraction, profile, and functional properties. Journal of Food Science, 76(1), R16R28. https://doi.org/10.1111/j.17503841.2010.01930.x.

Toledo, L. and Aguirre, C. (2016). Enzymatic browning in avocado (Persea americana) revisited: History, advances, and future perspectives. Critical Reviews in Food Science and Nutrition, 57(18), 38603872 .

https:// doi.org/10.1080/10408398.2016.1175416.

Tuncay, D. and Yagar, H. (2011). Comparison of polyphenol oxidases prepared from different parts of Artichoke (Cynara scolymus L.), International Journal of Food Properties, 14(4), 809-821, https:// doi.org/10.1080/10942910903453363.

Tungmunnithum, D., Elamrani, A., Abid, M., Drouet, S., Kiani, R., Garros, L., Kabra, A., Addi, M. and Hano, C. (2020). A Quick, green and simple ultrasoundassisted extraction for the valorization of antioxidant phenolic acids from Moroccan almond cold-pressed oil residues. Applied Sciences, 10(9), 3313. https:// doi.org/10.3390/app10093313.

Vamos-Vigyazo, L. and Haard, N.F. (2009). Polyphenol oxidase and peroxidase in fruits and vegetables. CRC Critical Review of Food Science 
Nutrition, 15(1), 49-127. https://

doi.org/10.1080/10408398109527312.

Van't Hag, L., Danthe, J., Handschin, S., Mutuli, G.P., Mbuge, D. and Mezzenga, R. (2020). Drying of African leafy vegetables for their effective preservation: the difference in moisture sorption isotherms explained by their microstructure. Food and Function, 11(1), 955-964. https:// doi.org/10.1039/c9fo01175g.

Vitali, A., Botta, B., Monache, G.D., Zappitelli, S., Ricciardi, P., Melino, S., Petruzelli, R. and Giardina, B. (1998). Purification and partial characterization of a peroxidase from plant cell cultures of Cassia didymobotrya and biotransformation studies. Biochemistry Journal, 331(2), 513-519.

Yıldız, G. (2019). Control of enzymatic browning in potato with calcium chloride and ascorbic acid coatings. Food and Health, 5(2), 121-127. https:// doi.org/10.3153/FH19013.

Zainol, M.K., Lew, H.W., Mohd Fauzi, N.I., Ng, K.S., Razman, N., Kadimi, N.F., Zamri, A.I., Mohd Zin, Z., Fisal, A., Chilek, T.Z.T. and Mamat, H. (2017). Antioxidative properties of selected microencapsulated plants powder prepared using ultrasonic spray-drying technique. Malaysian Applied Biology, 46(3), 41-49.

Zainol, M.K., Yi, W.K., Zin, Z.M., Kamarudin, K.S., Abdullah, M.D.-D., Shin, N.K. and Mamat, H. (2018). Effect of ethanol in ultrasonic assisted extraction technique on antioxidative properties of passion fruit (Passiflora edulis) leaves. Malaysian Applied Biology, 47(6), 19-27.

Zhu, M., Zheng, X., Shu, Q., Li, H., Zhong, P., Zhang, H., Xu, L., Wang, L. and Wang, L. (2012). Relationship between the composition of flavonoids and flower colors variation in tropical water lily (Nymphaea) cultivars. PLoS ONE, 7(4), e34335. https://doi.org/10.1371/journal.pone.0034335. 